\title{
Legal Electronic Institutions and ONTOMEDIA: Dialogue, Inventio, and Relational Justice Scenarios
}

\author{
Pompeu Casanovas ${ }^{1}$ \\ ${ }^{1}$ Institute of Law and Technology (IDT), Autonomous University of Barcelona, Bellaterra, \\ Barcelona-08193, Spain \\ pompeu.casanovas@uab.cat
}

Pre-publication. Please quote: P. Casanovas, Ugo Pagallo, Giovanni Sartor, Gianmaria Ajani (Eds) AI Approaches to the Complexity of Legal Systems (AICOL III) The Semantic Web, multilingual ontologies, multiagent systems, distributed networks AI Approaches to the Complexity of Legal Systems (AICOL I-II) The Semantic Web, multilingual ontologies, multiagent systems, distributed networks, Lecture Notes in Artificial Intelligence (LNAI), Heidelberg, Berlin, Springer Verlag, LNAI 6237, 2010, pp. 184-204.

\begin{abstract}
Since the seminal work by Perelman, Olbrechts-Tyteca, Toulmin, Ong, Giuliani and many others in late fifties and sixties, dialogue and argumentation have increasingly been at the center of philosophical discussions. Modelization of arguments and "argumentation schemes" constitute one of the main domains within the AI \& Law field. The construction of Legal Electronic Institutions (LEI), and Ontomedia, an Online Dispute Resolution (ODR) platform in the context of the research carried out within the Catalan White Book on Mediation, has enhanced the discussion about fundamental issues on the theoretical approach taken in building such Web 2.0 and Web 3.0 tools. In this paper, I will address the question of how the content of ancient stasis, ekphrasis and inventio may be captured and reelaborated to define their theoretical backbones. I will call "relational justice" the conceptual legal framework in which Semantic Web strategies can be nested to offer a better user-centered service.
\end{abstract}

Paraules clau: argumentation, dialogue, dialectic, rhetoric, Semantic Web, ODR, Electronic Legal Institutions, stasis, inventio, relational justice

\section{Introduction}

During the last year, the Institute of Law and Technology (IDT-UAB) and many other research Institutes and Universities in Catalonia are currently developing the Catalan 
White Book on Mediation. ${ }^{1}$ Those are the preliminary works to draft a general statute introducing and defining mediation as a complementary dispute resolution tool for courts, local and regional administrations (municipalities and regional councils, e.g.), and social and economic institutions (such as hospitals, schools, consumer agencies or chambers of commerce).

This is a sustained effort covering many fields of law — divorce and family problems, adult and juvenile crimes, labor conflicts, consumer complaints, commercial disputes, etc. Technology is certainly an issue. It is one of the areas being explored to set up online tools to facilitate business, citizens, customers and consumers to solve, or at least better manage, their disputes before suing and going to the courts.

A twofold strategy is being followed. First, in the spirit of the CONSOLIDER Project Agreement Technologies ${ }^{2}$ and the COST initiative ICO801, ${ }^{3}$ an automated protocol and negotiation prototype is under construction by Pablo Noriega and Carlos López using electronic institutions technologies [1]. Second, Ontomedia, a general platform for mediation services, is being developed within two adjacent national projects as well. Several objectives have been already reached. The state of the art of ODR services has been established and updated [2, 3], ${ }^{4}$ and a preliminary middle-out mediation core-ontology is ready to be populated and worked out [7].

In this paper, I will reflect on the general purposes and theoretical background of these approaches to foster an interdisciplinary dialogue, and to open up the discussion to a broader audience. The paper is structured as follows. I will introduce, first, Legal Electronic Institutions (LEI) and Ontomedia. Section 3 and 4 will reflect on their theoretical grounds, linking both strategies with the revival of the ancient traditions of dialectics, rhetoric and logic. Finally, in section 5, I will introduce the idea of relational justice to make sense of the technology and philosophical grounds described in the previous sections.

\section{LEI strategy and theoretical approach}

It may be quickly noticed that, in fact, there is not a unique generic platform under construction, but two. In what it follows, the two strategies and theoretical approaches will be briefly described.

\footnotetext{
${ }^{1}$ See http://libreblancmediacio.com

2 http://www.agreement-technologies.org/

${ }^{3} \mathrm{http://www.agreement-technologies.eu/}$

4 "None of the service providers reviewed seems to have truly sophisticated ODR technologies like the ones reported in academic fora." [1]. See the previous technical reports by Stranieri, Yearwood and Zeleznikow [4], Tyler and Bretherton [5], and Thiessen and Zeleznikow [6].
} 


\subsection{ODR as Legal Electronic Institution}

The prototype proposed by Noriega and López [1] is based on the notion of electronic institution (EI) and assembled through the EIDE tools developed in the IIIA. ${ }^{5}$ It corresponds to an attempt to automate as much as possible the ongoing interaction flow between two sides within conflict scenarios. In this situation, a multiagent system (MAS) may perform several interactive moves towards an eventual agreement. The whole process is plotted in Fig. 1, assuming a standard of nonintrusive mediation, arbitration and some forms of negotiation, not necessarily mediated.

I will follow briefly now the authors' own description. For a more complete and detailed explanation, the reader is invited to go directly to [1].

Electronic Institutions (EI) assume that all interactions are among autonomous agents, and that all interactions among agents are speech acts (that count as actions in the world). Noriega and López mention three main EI components: (i) the dialogical framework (specifying the content and interpretation of the admissible speech acts); (ii) the performative structure (indicating how the interactions are organized within the institution); (iii) the rules of behavior that put constraints on the actions (illocutions) that individuals who are playing a given role may take at some point in the enactment. When an EI is entitled to perform legal acts, or at the end of successive steps may produce a result with legal value, or an agreement that can be alleged in Court or before other appropriate ruling institutions, we face an Legal Electronic Institution (LEI). LEIs pose some interesting problems to the current legal theory that can be treated separately. I will not go deeper here.

The authors show the complete performative structure of a mediation institution in Fig. 2, where the first box and the last one correspond to scenes and dark boxes correspond to mediation activities: (i) a scene where the claimant chooses the type of negotiation she wants to use, (ii) four different negotiation conventions, (iii) a scene for standard non-intrusive mediation, (iv) and two ensuing scenes for arbitration and recommendation.

${ }^{5}$ http://e-institutions.iiia.csic.es 


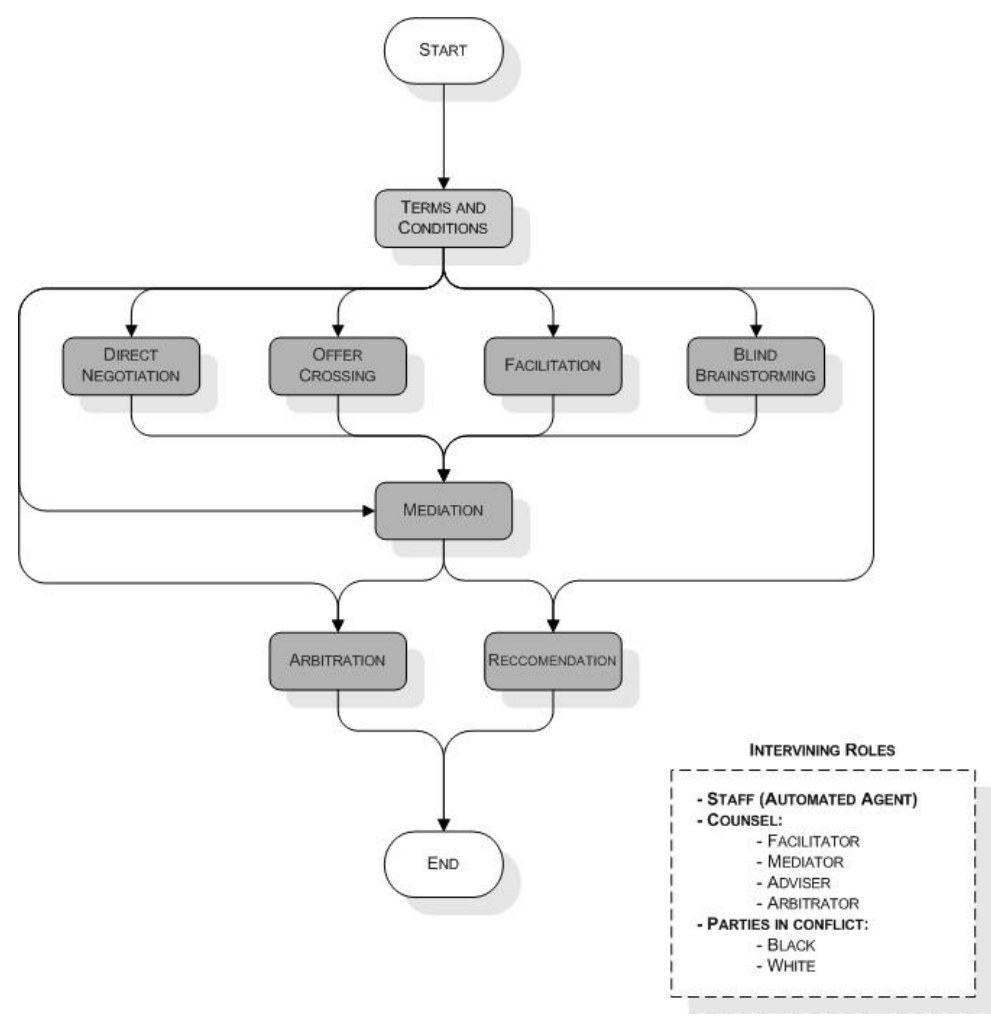

Fig. 1. Prototype structure. Source: [1]

The two starting and ending boxes start and terminate enactments. Lines connecting boxes (and widgets) indicate transitions, labeled with the roles that may move from one scene to another. In this particular institution three roles have been modeled: parties (the two sides of a mediation process), staff (taking care of institutional functions like time-keeping or record handling) and mediator.

It may be noticed that this performative structure allows different institutional ways of ODR (negotiation, mediation, arbitration) following iterative cycles. However, it is not necessary to complete one full cycle (e.g. negotiation). It may be possible to go directly to the arbitration process, if this is the case.

The important point is that in each separate box may be nested an autonomous argumentative process between the parties. This process may contain procedural rules which can be (at least partially) operated trough automated reasoning inferences. 


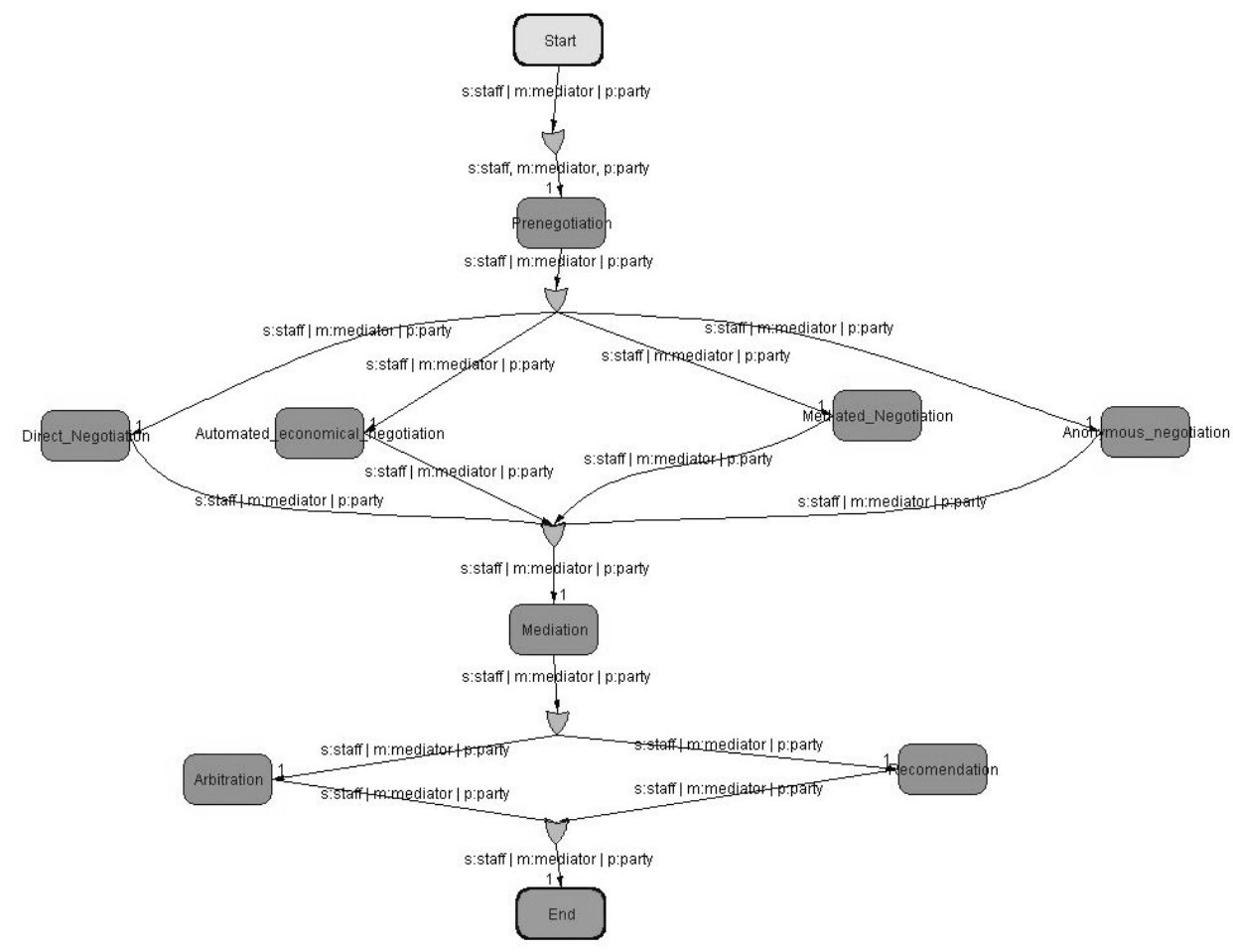

Figure 2. Performative structure of a Legal Electronic Institution. Source: [1]

\subsection{The Ontomedia strategy}

Let's go to the second model, now. Ontomedia follows a different strategy, a usercentered approach which takes into account a more restricted definition of negotiation and mediation as ODR institutional devices, following the spirit of the EU Directive $52 / 2008 .{ }^{6}$ It is not intended, at least primarily, to cover conciliation or arbitration issues. They are not excluded of the underlying model, but what is intended to build up is a multi-layered and indirect strategy to assist either lay or professional people in

6 Art. 3.a. “'Mediation' means a structured process, however named or referred to, hereby two or more parties to a dispute attempt by themselves, on a voluntary basis, to reach an agreement on the settlement of their dispute with the assistance of a mediator" ; art. 3.b. 'Mediator' means any third person who is asked to conduct a mediation in an effective, impartial and competent way, regardless of the denomination or profession of that third person in the Member State concerned and of the way in which the third person has been appointed or requested to conduct the mediation." It is worth to mention R. (9): "This Directive should not is in any way prevent the use of modern communication technologies in the mediation process." 
their dispute resolution processes. This is a platform to be used by citizens, administrations, institutions and professional mediators as well.

In a nutshell, Ontomedia will allow users and professionals to meet in a communitydriven Web portal where contents are provided by users and annotated by the ODR Web Platform [7, 8]. Its usability is tailored on the domains previously identified within the Catalan White Book: commercial and business disputes, consumer complaints, labor conflicts, family, restorative justice (adult and juvenile mediation in criminal issues), community problems, local administration, health care, environmental management, and education.

It is worth noticing that to the extent that these are broad domains, the platform is conceived as generic. However, the means used to solve or manage a conflict are close up to the nature of the conflict. In a quarrel among teenagers in a high school, race, culture, family and class may constitute separate issues. The dispute components may be different from those in a contract-breaching problem between providers and consumers. A collective quarrel about the placement of a new mosque-not an infrequent social problem in Spanish towns-usually requires different interventions and several negotiation techniques in addition to mediation. To the extent that such conflicts may need a set of different negotiation tools, the use of an online platform requires different functionalities linked to a previous definition of the available tools. This is usually called a "bus of services" or "service bus" [7, 8, 9].

Citizens (both professionals and users of mediation services) may use any kind of device to access the portal (computers, mobiles), and in any format suitable for their purposes (text, speech, video, pictures). We are confident that this flexibility will allow users to participate in mediation services as in a face-to-face basis, but with the advantages of distributed and even remote access.

Some ontologies are being constructed to annotate all kind of contents and also to help analyze multimedia content (see Fig. 3). The multimedia analysis is devoted to enhancing the information a mediator possess during a mediation session, capturing mood changes of the parties and any other psychological information that can be useful for mediators, just as if they were in a room with the users of the mediation service. All types of metadata can be automatically extracted and stored to be further used within the mediation process (provided the previous authorization by users).

Ontomedia will also develop tools to encourage users to exploit the advantages of sharing information and experiences with others. In this way, users have the possibility to tag and store content that are useful or interesting to them, and to find similar cases. In doing so, they can create social communities of people with common interests. 


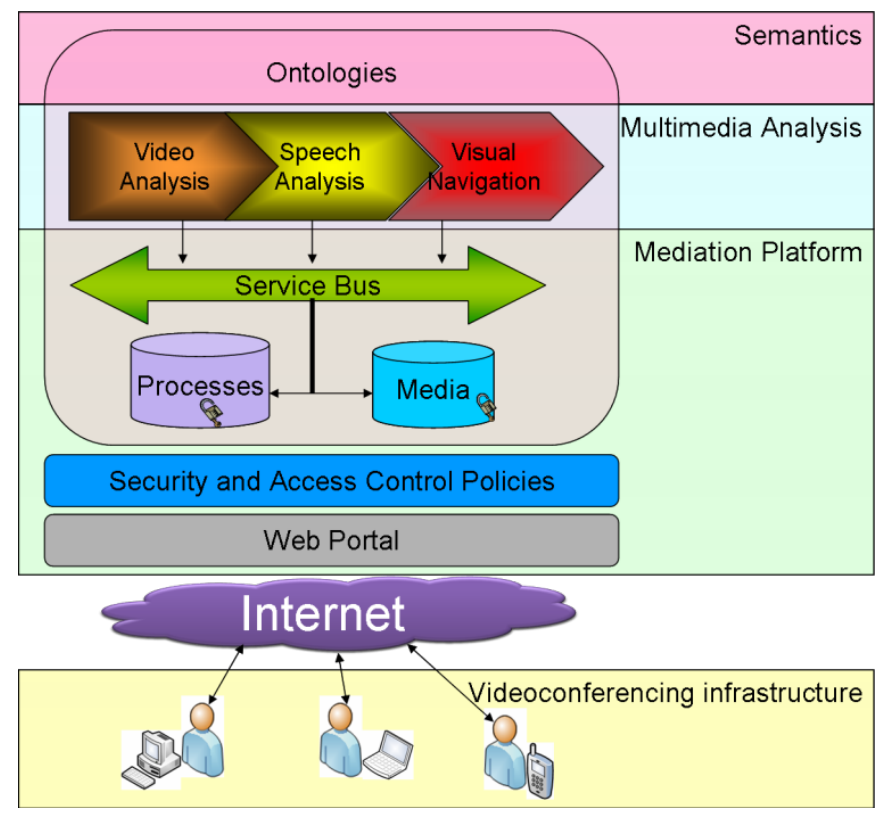

Fig. 3 Layered Diagram of Ontomedia Mediation Platform. Source: [8] [9]

\subsection{Inner and outer strategies between Web 2.0 and Web 3.0}

Conceptual models underlying strategies for the mediation LEI and Ontomedia are not incompatible, and they may be envisaged into the broader framework of the second generation of Semantic Web developments.

Both may comply with the features pointed out by Motta and Sabou [10, 11]: (i) reuse (vs. semantic data generation); (ii) multi-ontology systems (vs. single-ontology systems); (iii) openness with respect top semantic resources, (iv) scale as important as data quality, (v) openness with respect to Web (non-semantic resources), (vi) compliance with the Web 2.0 paradigm, (vi) openness to services.

LEI may incorporate the necessary flexibility to be interoperable and nested into a structure such Ontomedia. Easy and friendly access to justice can be offered through the so-called "Web of data". The usage of RDF Schema (RDFS) and the Web Ontology Language (OWL) allow the inference of relationships between data in different applications or in different parts of the same application. Objects, and not

7 "RDF Schema (RDFS) and the Web Ontology Language (OWL) provide the ability to infer relationships between data in different applications or in different parts of the same application. These Semantic Web languages allow for the assertion of relationships between data elements, which developers can use, via custom code or an emerging toolset, to enhance the URI-based direct merging of data into a single RDF store” [12] 
only websites, can be directly linked among them. Diagram of Fig. 4 shows a simple way to draw the encroachment between both LEI and Ontomedia. I have developed elsewhere what it does mean for future developments of law [13]. I have lean on recent work from James Hendler to analyze the link between the two approaches (Fig. 3). The first one remains highly theoretical, on top of the intertwined Webs 2.0 and 3.0, but able to be nested within the Ontomedia environment. The second, on the contrary, offers a park of legal services on mediation.

\begin{tabular}{|c|c|c|}
\hline \multicolumn{2}{|c|}{ Electronic Legal Institution (ELI) } & $\mathrm{O}$ \\
\hline Web 3.0 & & $\mathrm{~T}$ \\
\hline \multirow[t]{2}{*}{ Web 2.0} & $\begin{array}{l}\text { Semantic Web } \\
\text { (RDFS, OWL) }\end{array}$ & $\begin{array}{l}M \\
E\end{array}$ \\
\hline & $\begin{array}{l}\text { Linked Data (RDF, } \\
\text { SPARQL) }\end{array}$ & $\begin{array}{l}\mathrm{I} \\
\mathrm{A}\end{array}$ \\
\hline
\end{tabular}

Fig. 4 James Hendler's diagram (with permission). Source: [12], modified by P.C.

\section{Discussion: Dialogue, Dialectic and Rhetoric}

I will split up the discussion of the legal philosophical groundings of these models in two different parts. For the sake of clarity, in this section I will consider the general foundation for dialogue, and the revival of dialectic and rhetoric in argumentation and philosophy of law. Section 4 will face the pragmatic developments of such a revival.

It would be naïve to link the whole conception to a single philosophical source. LEI models follow previous theoretical approaches made by Douglas North (on institutions) [14], Cristiano Castelfranchi (on rationality, and normative and interactive behavior - trust, deception...) [15], and John R. Searle (on speech acts and social institutions) [16]. Collective properties emerging out of the process, and the accurate conceptual representation of the whole process (e.g. turn taking, decision making, iterative cycles, and final move forward...) are taken into account.

It seems to me that the disputation model figured out by Noriega and Lopez fits nicely into the main flow of contemporary argumentation theory and formal dialectic systems. However, it should be immediately noticed that the main structure of the 
proposal is not necessarily related to automated reasoning, but rather to the way of conceiving the architecture of the system of dialogue interactions.

\subsection{Dialogue Systems}

Dialogue systems built up in the AI \& Law domain use to be symmetrical, iterative, cyclic and procedurally-driven [17]. Legal procedural rules have received a privileged attention [18], and their main requirements are defining the parties, describing their positions, and setting a controlled step-by-step process to manage the disputes. The ODR model recently presented by J. Zeleznikow, A. Lodder and E. Bellucci [19, 20, 21] is following this well-trodden path too. It combines game-theory, case-based reasoning and the Harvard model for dispute resolution (BATNA) to offering advice in divorce situations.

The main dialogue structure assumed by all these developments comes from the ancient dialectic and has been described several times by D. Walton [22, 23] as the "fundamental building blocks" of any dialectical system: (i) the two participants, called the proponent and the respondent, (ii) the types of moves (taking the form of various speech acts) that the two participants are allowed to make, as each takes his or her turn to speak, (iii) the sequence of moves, in which the appropriateness of each move depends on the type of preceding move made by the other party, (iv) the goal of the dialogue as a whole.

Walton identifies four kinds of moves in such systems: (i) the asking of questions, (ii) the making of assertions, (iii) the retracting of assertions, and (iv) the putting forward of arguments.

Similarly, dialogue types may be classified according to their main objectives as follows: (i) persuasion, (ii) inquiry, (iii) negotiation, (iv) information-seeking, (v) deliberation, (vi) eristic. These types of dialogue would proportionate the main scenarios in which different dialogues may take place.

From a legal point of view, stemming from a goal-oriented approach, Sartor has expanded this taxonomy adding three more types of dialogue: (i) epistemic inquiry, (ii) practical inquiry, (iii) and reconciliation [24].

This means that such a structured valued framework - more specifically, a teleological notion of law as a cognitive technology being organized through a valid normative system - may determine the structure of dialectic interactions.

Sartor's position is far from simple. The thesis is "that legal reasoning has a collective (interactive) dimension, in regard to which diverse dialectical patterns may be required, according to the goals to be achieved and the context in which they are to be pursued" [24].

I would say that this collective, interactive dimension, especially if it is produced through the Internet, is a regulatory one. There is a regulatory order that emerges out from the interactions. However, not all regulatory patterns are "law" or "legal" in the normative sense. Law components, as we know them so far -i.e., rules (norms), statutes, judicial decisions, rulings, and legal rights and duties - have to be combined with social emergent patterns of behavior and social rights and duties to operate through the Web. Governance, soft-law, reputation systems and, especially, trust, are not mandatory elements. Dialectic systems and argumentative models have to 
represent conceptually this kind of hybrid, mixed, mashed-up scenarios as well if they are going to be used or taken into account.

\subsection{Dialectic, Rhetoric and Logic}

This is linked to another line of arguments. But I should warn the reader at this point that I will follow a historical thread. Only at the end I will come back to the mediation models. The main scope of this historical turn is setting a broader interpretative legal context on dialogue and law in which our proposals may acquire an added sense to be properly understood and evaluated.

It seems to me that Walton and Sartor's taxonomies, and the procedural way in which they face the modeling of dialogues, are deeply rooted in a conception of reason that stems from the classic (and complex) relationships between logic, dialectic and rhetoric. It has been observed many times that ancient dialectic and rhetoric have a strong legal flavor. Dialectic mirrors legal dialogical controversies, and ancient rhetoric, as it may be found e.g. in the works by Cicero and Quintilian, mirrors speeches in judicial settings [25, 26].

Leff [27] sketches four points of contrast between the two disciplines: (i) dialectic deals with general, abstract issues, rhetoric with specific, circumstantial issues; (ii) dialectic considers the link of propositions and follows logical rules of rationality, rhetoric considers the relationship between propositions and situations and follows rules (or norms) that refer to appropriate social relationships; (iii) dialectic proceeds through question and answer (and the interlocutors seek to persuade each other), rhetoric proceeds through a flow of uninterrupted discourse, and the speakers seek to persuade the audience; (iv) dialectic employs a technical language, rhetoric uses plain natural language for persuasive purposes.

This is a schematic, but still useful summary to realize the complexity of the issue. Regarding logic, Aristotle and the ancient tradition tried to maintain separated reasoning related to truth, dialogical reasoning regarding opinions and beliefs, and the places or topoi regarding the ways in which these beliefs are conveyed and shared (that is to say, rhetoric). The medieval tradition played endlessly with those distinctions, until the coming of Humanism in the $15^{\text {th }}, 16^{\text {th }}$ and $17^{\text {th }}$ centuries. Conflicts, disputes, controversies, were placed at the center of this ars discendi et disserendi [28].

It is generally accepted by historians of philosophy that the humanist tradition of German, Dutch, English and Italian Universities [29, 30, 31] worked out the Greek and Latin texts and mixed up the medieval syllogistic logic (e.g. from Petrus Hispanus) to elaborate an educational discourse, more adapted to everyday life, to social and economic new problems, and to the structures of political power of the recently born European states. Even the Catholic and Imperial Spain, crashed under the Inquisition, received their impact [32, 33].

Dialogue emerged at the beginning as a new framework to contain the classical topoi; and, in this way, logic became a part of dialectic. That is to say, inner discourse with the soul could convey truth (and not only beliefs), and outer discourse could reflect the moves of what was intended as "thought" (and not only language). 
Rhetorical speech (verba) was the way to concrete this thought in different dramatic, legal or political scenarios [28].

There is a string line going from the works by Agricola, Melanchton and Sturm, to Talon and Ramus [34, 35]. This common thread was cut up with the violent defeat of Ramism and the Jansenist Logic of Port Royal under the Ancient Régime. But it was weaved by protestant countries and transferred into the common law [36, 37].

Interestingly enough, the subject/object philosophical approach was reversed in this long history, as the judicial object was. ${ }^{8}$ Paradoxically, it was the influence of Ramism into judicial procedures what excluded the discussion of facts out from dialogue and left them entirely to the decision of an authoritative judge. As W. Ong [39], C. Perelman [40] and A. Giuliani [37], among others, explain, a judicial asymmetric order would substitute to the isonomic order of ancient dialectic. ${ }^{9}$

It would be worth noticing here that almost all the discourses on the revival of ancient dialectic and rhetoric in the second half of the $20^{\text {th }} \mathrm{c}$. escape the response to the question of what happened in between with the topics of legal dialectic and rhetoric during the $18^{\text {th }}$ and $19^{\text {th }}$ centuries. This is surprising, because we have detailed accounts on humanistic and rationalistic thought. It seems that dialogue had just disappeared from legal and political theory.

Still, this is not an easy issue. However, at least regarding to legal reasoning, the answer could lie on the prevailing of syllogistic judicial reasoning after the Code de Napoleon (1804), and the coming of the German Historical School, Pandectas and the conceptualist schools of law. The answer points then to the establishment of a new political and administrative form of government called Rechtstaat, État de Droit, Estado de Derecho, Rule of Law, in which the old topoi were subjected to the procedural ring of constitutions and systems of legal norms. However, as Tocqueville early noticed [L'Ancien Régime et la Révolution, 1856], all the legal administrative apparatus (including the judiciary) of the legal state built up in the Ancient Régime would remain along the Enlightenment and the $19^{\text {th }}$ century.

\subsection{The legal methods}

I will pursue elsewhere this historical explanation [41]. The point I would like to stress here is that, with independence of the guaranties, constraints and requirements of the judicial decision, the modern state, and not society, community or individual interactions, built up the main framework for the setting, procedures, roles and development of legal arguments. Under those conditions, arguments, topoi, places and reasoning were bound to be put under a legal interpretation theory (the legal content of Sätze, Instituta, Normen or rules addressed to an authoritative judge). "Legal

${ }^{8}$ Pozzo [32] has shown convincingly how the pair of Greek concepts 'subject' (hupokemeinon) and 'object' (antikemeinon) actually mean the opposite of their post-Cartesian usages. The former refers to what we call today a formal approach (the logical mind), and the latter to the investigative activity of senses (the subjective conditions of experience).

9 « Puisque la preuve judiciaire n'est pas différente de la preuve scientifique. Il faut que controverse et dialogue soient exclus du procès; la 'questio facti' — considérée comme autonome par rapport à la 'questio iuris'— est confiée tout court à l'arbitrium iudicis » [37]. 
method" or the "science of law" were the umbrella under which this interpretative turn took place.

In this way, from Savigny, Puchta, Jhering and Gerber $\left(19^{\text {th }}\right.$ c.), to Gény, Jellinek, Kelsen and Hart $\left(20^{\text {th }}\right.$ c.), dialogue was definitively excluded from law and legal theory, and left to the more "insecure" domain of political arena or private economic markets. Decisions were placed under a set of norms which would constitute the choice for a judicial syllogism, based on the burden of proof and the consistency of a non-contradictory argumentation as warrants or pre-requisites for the judicial induction —assigning probable truth values to inferences sorted out from premises containing insufficient information.

Along with fallacies, these constitute precisely the points chosen by Walton to reelaborate the problem of innovation and creation of new arguments [23, 42]. This goes directly to the core of one of more pervasive and persistent problems of cognitive sciences and philosophy. How the potential creativity of the mind can be described and explained? Are there rules or patterns to be followed for innovation? Or, as the ancient philosophy would put it, how can be filled up the gap between rhetoric and logic?

\section{Discussion: Pragmatics, mediation, and innovation}

Argumentation schemas may be defined as "forms of arguments representing premise-conclusion and inference structures of common types of arguments" [43]. For Walton's "new dialectic" the old topoi, loci or places constitute "defeasible argumentation schemas" to be combined and aligned to produce a full chain of reasoning. Argument schemas are presumptive and open to revision and change.

As we will see, these inferences are conceived to be "rationally binding" between the participants engaged in any dialogue [42]. This approach fits particularly well in a judicial perspective, in which either the judge or the lawyer have to find new and convincing arguments to sustain proof. According to Walton's proposal, the gap between logic and rhetoric may be filled up leaning gradually on the identification, analysis, and evaluation processes (dialectic), and on the innovative one (rhetoric). Heuristics are used to find new arguments, but the crucial point is called dialectic relevance, a method of chaining both forward and backward to get the chain of argumentation to match up in the middle [23, 42]. The whole process is recursive and iterative, going from (i) acceptable premises to (ii) rules of inference, and (iii) a chaining recursive device. Diagrams may be plotted for visualization. ${ }^{10}$

\subsection{Dialectic Systems and Pragmatics}

Dialectic relevance is not the only way proposed to connect truth and persuasion. There is another tradition to be taken into account. Models by Sartor, Walton and Lodder lean heavily on logic (dialectic). On the contrary, the second set of models stems from pragmatics and focus on communication.

${ }^{10}$ http://araucaria.computing.dundee.ac.uk 
Pragma-dialectics is an approach to argumentation which tries to combine both perspectives, but leaning on the use of language for resolving disputes [44]. Walton's pragmatic perspective on conversation tries to deepen into it to reconstruct the propositional content of the hidden or tacit arguments of both sides: their "argumentative reasoning patterns" [43]. On the contrary, the Pragma-dialectics school (van Eemeren, Grootendorst, Jackson, Jacobs...) lean on the techniques of practical persuasion. They define dialectics as "a method of regimented opposition" in verbal communication and interaction "that amounts to the pragmatic application of logic, a collaborative method of putting logic into use so as to move from conjecture and opinion to more secure belief" [44]. Therefore, they are much more interested in the effects of communication than in its truth. They consider three different aspects of "strategic manoeuvring": (i) the topical potential associated with a particular discussion stage, (ii) the audience demands in this stage, (iii) the presentational demands appropriate for the moves made in that stage.

It is worthwhile to mention here that we owe to the works carried out by Jackson [45], Jacobs [46], and Aakhus [47, 48, 49] some detailed accounts of mediation experiences and practices. The new wave of Pragma-dialectics faces the "pragmatic reconstruction" of arguments ${ }^{11}$, the "collaborative design of the disagreement space", and the types of rationality that mediators employ in interpreting conflict situations (critical discussion, bargaining, and therapy). "We do not take the central problem of pragmatics to be how communicators assign functional meaning to specific messages or disambiguate speaker intention, but how is that people mutually negotiate social activity with language and thus participate in everyday life" [50].

\subsection{Inventio and judicium}

Both ways to tackle innovative arguments have their roots in dialectics and rhetorics. However, it seems to me that this second perspective takes more into account the shift of Humanist tradition we mentioned before, and more specifically, the discursive side of Agricola's notion of dialectic.

Rudolf Agricola (1444-1485) set a phenomenology of language and speech which originated a revolution in the way old rhetorical texts were interpreted [51]. We may find in his major contribution, De Inventione Dialectica Libri Tres (1479) at least five new starting points that lead to an abductive notion of interaction and reasoning: (i) human interaction as a negotiated and complex shared dialogical object (ii) thought as a product of discourse (speech), (iii) cognitive and emotional empathy as the basis for a common human (inner and outer) understanding, (iv) context as a shared sequence of already known scenarios which help the selection of features given to a term to produce meaning, (v) discovering as a collective process to build a systematic path through dialectic from the known to the unknown.

We usually find in the literature on Agricola that his notion of place and his taxonomy of topics would allow him to reason in a new pedagogical way, but through

11 "The hallmark of pragmatic reconstruction lies in the way a form of argumentative dialogue is tailored to circumstances of the dispute in order to achieve a particular type of outcomes" [47]. 
the syllogistic "middle term" that would relate his logical perspective to the Middle Age and not to the formal developments of Descartes and Leibniz. ${ }^{12}$ Agricola extends the scope of dialectic to include all kind of (reasoned) discourses, and the places of dialectic to the level of concepts. Doing so, his philosophy attends less to the truth and validity of arguments than to their effects.

This is right. But we may interpret it as "psychologism" or, from a cognitive science perspective, as closer to contemporary notions such as "schema", "script", "folk model", "category" and "difference".

As it is well known, the art of rhetoric was divided in five parties: inventio, dispositio, elocutio, memoria and declamatio. During the Renaissance, Inventio was situated as the first part of dialectics, while its second part, judicium, was supposed to temper, modulate and guide in a syllogistic manner the subject matter discovered or created in the first one [51]. ${ }^{13}$

Agricola argues for an extension of places or 'seats of arguments' related to the nature of language "by whose instruction as if by signs of some sort [velut signis quibusdam], we surround the mind with the things themselves and thereby perceive what is in each thing both probable and suitable to the purpose of our discourse" [Inv. I, 1], "A place therefore is nothing else but a certain common characteristic of a thing [communis quedam rei nota], by observing which all that is probable about a given thing can be discovered. Let then a place be so defined by us.” [Inv. I, 2] [52, 53, 54].

\subsection{Stasis and ekphrasis}

Stasis (status) is the proper manner of discovering the question to be answered in every situation. Ekphrasis (descriptio) is the ability to elicit suitable contents on any subject from any of the places: the description of one term relatively to another to discover agreement and difference.

Status, in the classical rhetoric of Hermogenes, Cicero, and Quintilian, intended to define the different stages of a judicial plea between accusation and defense. It was translated into the common law tradition as issue (e.g. by Thomas Wilson and Blackstone), although this legal term does not express exactly the original meaning [55]. First, the status was supposed to give the litigants an understanding of their dispute through a categorization of the conflicting statements. But it indicated too the

\footnotetext{
12 See e.g. [39], following Bochenski.

13 'The instrument of 'inventio' was one of the main tools of classical rhetoric, and paired with judicium, it was the first and most important of the five parts of classical rhetoric. It was the art of finding and searching suitable ideas, reasons and arguments for a specific purpose, by using the search formulas 'topoi' or 'loci'. These 'arguments' were intended to approach the truth as closely as possible, and were often classified according to the dominant means of persuasion: by employing reason or logic (logos), arousing emotion (pathos), or demonstrating trustworthy character (ethos). But the instrument of inventio did not so much intend to lead the user to new metaphysical insights; is purpose was of a more practical nature, it was designed to produce an object or work: a poem, a speech, an emblem or proverb, etc...” [51, esp. chap. 2]
} 
disposition to reason and to debate what the conflict was about. ${ }^{14}$ There is a procedural dynamic within the status.

We should emphasize here the visual or pictorial side of the arguments as conceived dialectically: ekphrasis is the graphic or discursive description in visual terms of stasis [56]. People, literally, may see in one single shot the object of dispute and the content of the arguments used to describe their positions and to eventually solve the issue at dispute.

To Agricola, language, but also the interactive capacity of the mind to recognize and understand other minds, are extraordinary important to depict this narrative object and to convey emotions: "To me an emotion seems to be nothing else but a certain impulse of the mind by which we are driven to desire or avoid something more intensely than we would in a calm state of mind. Every emotion, therefore, arises from interest in objects of desire or avoidance. We desire whatever things are in fact or in appearance good, and we avoid those which are, or are felt might be, harmful. Nor are we moved only by those things which we think are good or bad for ourselves; we also grieve, rejoice, become angry or sad because of the situation of another." (emphasis added) [De Inv. III.1] [52]

\section{Relational justice: dialogue, abduction and reasoning}

There are several ways to understand the old tradition of dialectic and rhetoric from contemporary theory of argumentation. Logical, rhetorical and dialogical approaches are usually considered as theoretically different [57]. Stasis and ekphrasis may be considered from the dynamics of the strictly judicial point of view [26], in which the issue at stake is identified with the object of dispute, or from a broader perspective, in which stasis is produced through an abductive process of reasoning among the different parties [55]. Similarly, it seems to me that the old notion of ekphrasis may be (partially) captured by the notion of visual abduction [58].

\subsection{Mediation as a transformative process}

Context, environment and possible argumentation scenarios constitute a big issue. There is a common trend towards normativity in the contemporary argumentation theorists: (i) implicit contexts considered as norms within the language and discourse [59, 60], (ii) implicit contexts linked to types of dialogues that guide the functioning of dialectical relevance [22, 23], (iii) implicit contexts linked to the notion of practical reasoning and intention [24], (iv) implicit contexts linked to the environment of Multi-Agent Systems, where actions of electronic agents shape a social and institutional behavior [15] (v) implicit contexts linked to a pragmatic normative

\footnotetext{
14 "The suggestion that the status or issue had to be espied, that it was not given, that questions required work, that, for issue to be joined, much debating was sometimes necessary is characteristic of the common law pleading tradition.” [55]
} 
version of dialectic, in which "dispute mediators, in the course of their work, perform normative construction like a critical analyst” [49].

Perhaps the legal perspective of the old rhetoric still weights in the way norms are conceived. However, with mediation processes in mind, the construction of the "inner" and "outer" environments through dialogue—in Herbert Simon’s sense [61] — is not a predetermined task. In a mediation process, in real conflicts, contexts may shift within types of dialogues, and they cannot be easily categorized as belonging to a single type. Imagination, or "moral imagination", as Paul Lederach puts it, is an essential feature of mediators [62]. Listen to this narration from a professional mediator:

Two guys take a car after having a drink. The guy who was driving was not the owner of the vehicle. The car went up in fire and the driver could get out and save his life. The other guy died. The mediation process takes place two years later between the mother of the dead guy and the surviving driver. He asks for mediation. The mediator (a woman) ought to understand de conflict first, and she prepared the individual session with the mother. The key questions were: How do you feel? Because I believe that you blame yourself, while everyone knows that you are not guilty at all; who are you angrier with over the death of your son? She cried for more than 30 minutes, and so did the mediator. They embraced each other. They went for a coffee. In a week there was no more need for mediation. She could rebuild again her relationship with him without being helped, and she could accept as well the therapy that she had been rejecting so far. ${ }^{15}$

Some of the taxonomies built up to capture these transformative features reflect this creative character, especially in hard cases of restorative justice [63]. Victimoffender mediation styles may be also combined to form typologies of dialogue, depending upon the ordered preferences of the different styles: (i) therapeutic (mediator-conducted), (ii) empowerment (victims' healing, offenders' assumption of responsibility), (iii) or narrative (management of the memories and expression of feelings) (Fig. 4).

\begin{tabular}{|l|l|l|l|}
\hline & Type I & Type II & Type III \\
\hline Rank OF* & Therapeutic & Narrative & Empowerment \\
\hline Rank OF & Narrative & Empowerment & Narrative \\
\hline Rank OF & Empowerment & Humanistic D. & Therapeutic \\
\hline Examples & $\begin{array}{l}\text { Canadian } \\
\text { VOM }\end{array}$ & $\begin{array}{l}\text { Humanistic } \\
\text { Mediat. Dial. }\end{array}$ & Ohio VOD \\
\hline
\end{tabular}

* Rank Ordered Foci

Fig. 5 Victim-sensitive Offender Mediation Typology. Source: Adapted from [64]. Umbreit, Bradshaw and Coates were reporting on crimes with severe violence.

15 I thank Maria Munné (mediator), for writing down this personal communication. 


\subsection{Ontomedia and LEI}

Let's go back now to the models underlying Legal Electronic Institutions and Ontomedia. After the examination of some of their philosophical foundations, our conclusion is similar to Leff's assertion: "In sum, neither the rhetoric of effective persuasion nor the logic of rational persuasion should adopt theoretically purified goals.” [27]

Fig. 6 shows how LEI and Ontomedia strategies may be related. The rational side of dialogue an its discursive, expressive or emotional side are understood not as separate sets of discrete entities but rather as a continuum covering intertwined processes and outcomes. The link between inventio and judicium, or between the propositional content of assertions and creative innovative moves, can be assumed following the same continuum line.

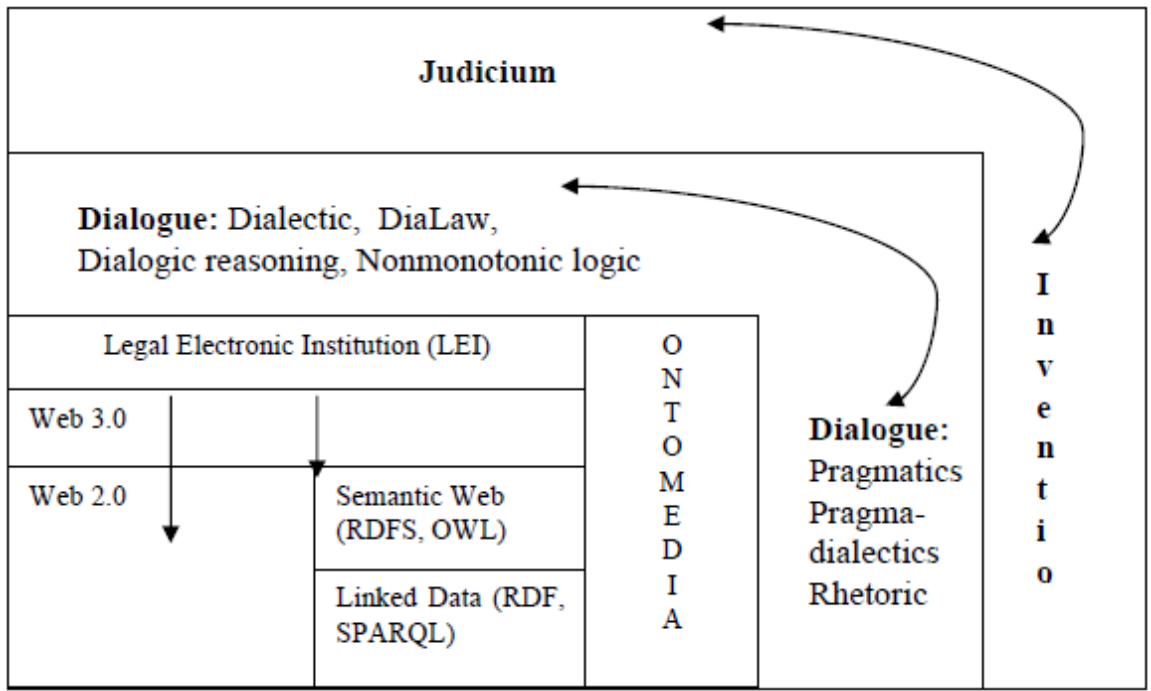

Fig. 6 Dialectic and rhetorical links related to LEI and ONTOMEDIA.

This continuum is not meant to equate eclectically different theoretical trends. Differences can and should be maintained. Contemporary argumentation theories closer to the dialectic approach tend to assume speech act theory, felicity conditions and rules of inference, combined with some heuristics. Non-monotonic logic is usually applied leaning on Toulmin's shoulder. Pragma-dialectics, on the contrary, lies more on the heuristic side of rhetoric and explicitly rejects speech act theories based on non-situated or unbound conditions [50]. Still, Ducrot's notion of argumentation dans la langue leads to a semantic notion of pragmatics in which every utterance has an enunciative and argumentative value [60].

However, LEI and Ontomedia may adopt different notions of pragmatics and different pragmatic approaches as well that may be combined and operated according to the chosen functionalities. 
Ontomedia adopts a user-centered approach, in which the professional mediator may chose among a box of tools to perform her work. LEI tends to guide the user through a process that automates the procedural parts of mediation through successive stages.

\subsection{Web 3.0 and relational justice scenarios}

Justice, reason and argumentation have been linked to power since the beginning. It would be naïve, then, trying to understand the functions, intentions and meaning of Greek and Latin literature on the subject without any understanding of the underlying principles of ancient societies. To put only one example, the Aristotelian notion of "distributive justice" is better understood through some notion of the market (or "proto-market") in which distributive problems arose and the concept was coined [65]. Recent empirically-based studies on organizations state clearly that "justice and power are intertwined: one cannot really understand justice dynamics without understanding power dynamics and vice versa, because the concern for justice acts check on the use of power" [66].

As I showed before, conflict and argumentation as we know them today are linked to the emergence of the modern state. Legal reasoning has been historically shaped as well through concepts, procedures and structures related to a kind of judiciary often tensioned by the king and parliamentary powers. Not surprisingly, rhetoric and reason in the $16^{\text {th }}$ and $17^{\text {th }}$ centuries are linked to the emergence and counterbalance of raison d'état $[67,68]$.

Therefore, Ontomedia and LEI cannot be conceived in a vacuum, but having into account that new scenarios of conflict resolution and management are arising in the broad technological environment of the Internet. It is my contention that the implementation and use of technology changes the nature of law, in any way we may conceive it. Through the Internet environments, law cannot be defined solely as related to the national state or even to the institutions of the Rule of Law, but to all the regulatory devices at stake, including languages, protocols, electronic agents and reputation systems.

Therefore, disputes, controversies, and conflicts may be better represented and nested as scenarios of relational justice. In computing, a scenario is a representation of the types of interactions end-users will maintain with the system, the way in which the system faces the interface with them in their daily activity. In the case of Ontomedia, the different domains from the White Book on Mediation (health, education, family, consumers' complaints, and so on) are being used as scenarios. What these scenarios have in common is that they have been chosen and constructed in social fields where some experiences on mediation and Alternative Dispute Resolution (ADR) have already arisen.

This means that these are fields in which some conflicts (social, political or economic) have originated some kind of social bottom-up resilience to fix the problem. In some cases as well, increasingly, administrations have reacted to give the opportunity to citizens to maintain a more effective interaction with them. In both cases, some forms of Online Dispute Resolution can be (or have been already) adopted. Therefore, we have chosen a middle-out strategy as ontological 
methodology, and we have situated our intervention under the label of relational justice.

I broadly define relational justice as the justice through the Internet, that is to say, by means of a technological framework in which controversies, disputes, conflicts and litigation may be managed (and sometimes solved) online, or in a mixed combination of economic, social or political organizations and institutions [3,13]. It is important to keep in mind that these scenarios of relational justice do not belong exclusively to a virtual reality, but rather to the interface between the Web and the real world. Therefore, they may be used in several ways, and systems and platforms may contain a set of tools to be used only in a single phase of the conflict or in some steps of the process.

\section{Conclusions and Further Work}

I have briefly examined in this paper the rational grounds for the two strategies for ODR being followed in the context of the Catalan White Book on Mediation. Several historical threads have been followed to understand the roots of the revival of argumentation theories. I have argued that history has to be taken in a whole, explaining the contexts in which models of state and legal methodology emerged.

I have showed how dialectical and rhetorical traditions may be assembled to produce a technological outcome.

Rationality is another issue. Normative approaches can be tempered with a vision of rationality taking into account the expressivity and creative heuristics of the stakeholders [69]. It is worth to point out that at the present level of Web 2.0 and 3.0 developments, rationality is affected by the integration of data. This will have an impact on the original models of dialectic, rhetoric and argumentation.

E.g., scalability affects reasoning: "[...] because the Semantic Web combines heterogeneity, variable data quality, and scale, the applications we envision will exhibit intelligent behavior owing less to an ability to carry out complex inferencing than an ability to exploit the large amounts of available data. That is, as we move from classic KBSs to Semantic Web applications, intelligence becomes a side effect of scale, rather than of sophisticated logical reasoning. An important corollary here is that, as logical reasoning becomes less important and scale and data integration becomes key issues, other types of reasoning — based on machine learning, linguistic, or statistical techniques - become crucial, especially and because they frequently need to integrate and use other, non-semantic data" [11].

These conditions concerning the Web environments have to be integrated in the design of platforms and tools.

Finally, in the next future, use cases and cognitive walkthroughs will be developed, measured and tested in some relational justice scenarios. 


\section{References}

1. Noriega, P., López, C. Toward a platform for Online Mediation. In: M. Poblet, U. Shield, j. Zeleznikow (eds.) Proceedings of the Workshop on Legal and Negotiation Support Systems 2009, in conjunction with the 12th International Conference on Artificial Intelligence and Law (ICAIL 2009), Barcelona , June $12^{\text {th }}$ (2009), IDT Series n. 5, pp. 67-75 http://www.huygens.es/site/service4.html, CEUR482, http://ftp.informatik.rwth-aachen.de/Publications/CEUR-WS/Vol-482/

2. Poblet, M., Noriega, P., López del Toro, C., Suquet, J. Mediación en línea: estado del arte y escenarios de uso. In: P. Casanovas, L. Díaz, J. Magre, M. Poblet, Materiales del Libro Blanco de la Mediación en Cataluña, Barcelona: Generalitat de Catalunya, Departament de Justícia, Centre d’Estudis Jurídics i Formació Especialitzada, pp. 159-169 (2009)

3. Casanovas, P., Poblet M.: Concepts and fields of Relational Justice. In: P. Casanovas, G. Sartor, N.Casellas, R.Rubino (Eds.) Computable Models of the Law. Languages, Dialogues, Games, Ontologies., LNAI 4884, Berlin, Heidelberg: Springer Verlag, pp. 323-339 (2008)

4. Stranieri, A., Yearwood, J., Zeleznikow, J.: Tools for World Wide Web based legal decision support systems, ICAIL-2001, St. Louis, Missouri USA., ACM, pp. 206-214 (2001)

5. Tyler, M.C., Bretherton, D.: Seventy-six and Counting: an Analysis of ODR sites. In: A, Lodder et al. (ed.) Essays on legal and technical aspects of Online Dispute Resolution. Papers from the ICAIL 2003 ODR Workshop, june 28, 2003, Ediburgh, Scotland, UK, pp. 13-28 (2003)

6. Thiessen, E.; Zeleznikow, J.: Technical Aspects of Online Dispute Resolution: Challenges and Opportunities, Thiessen E and Zeleznikow, J. Technical aspects of ODR: Challenges and opportunities. In Conley Tyler M, Katsh E and Choi D (eds) Proceedings of the Third Annual Forum on Online Dispute Resolution. The International Conflict Resolution Centre, The University of Melbourne in collaboration with the United Nations Economic and Social Commission for Asia and the Pacific (2005)

7. Poblet, M., Casellas, N., Torralba, S., Casanovas, P.: Modeling Expert Knowledge in the Mediation Domain: A Middle-out Approach to Design ODR Ontologies. In: N. Casellas, E. Francesconi, R. Hoekstra, S. Montemagni (eds.) Proceedings of the 3rd Workshop on Legal Ontologies and Artificial Intelligence Techniques joint with $2^{\text {nd }}$ Workshop on Semantic Processing of Legal Text (LOAIT’09), Barcelona, June 8, IDT Series n. 1 pp. 19-28 (2009) http://www.huygens.es/site/service4.html

8. Poblet, M., Casanovas, P. López-Cobo, J.M: Online Dispute Resolution for the Next Web Decade: The Ontomedia Approach, ITAIS-09, Sardinia, Costa Esmeralda, October 5th (2009)

9. Poblet, M., Casanovas, P., López-Cobo, Cabrerizo, A., Prieto, J.M.: Mediation, ODR and 2.0: A Case for Relational Justice, AICOL-09 in conjunction with JURIX-09, Rotterdam, December 16th (2009)

10. Motta, E., Sabou, M.: Next Generation Semantic Web Applications, Mizoguchi, Shi y Giunchiglia (Eds.) ASWC-2006, The Semantic Web, LNCS 4185, Heidelberg, Berlin: Springer, pp. $24-29$ (2006)

11. D’Aquin, M., Motta, E., Sabou, M., Angeletou, S., Gridinoc, L., Lopez, V., Guidi, D.: Toward a new Generation of Semantic Web Applications, IEEE Intelligent Systems, May/June, pp. 20-28 (2008)

12. Hendler, J.: Web 3.0 emerging' (january 2009), IEEE Intelligent Systems, pp. 88-90 (2009)

13. Casanovas, P. "The future of law: Relational Justice and Second Generation of Semantic Web Services”, in M. Fernández-Barrera et al. The Future of Law, EPAP, Florence (2009)

14. North, D.C.: Institutions, Institutional Change and Economic Performance, Cambridge: Cambridge University Press (1990)

15. C. Castelfranchi, Limits of strategic Rationality for Agents and M-A Systems, in Multi-Agent Rationality, LCNS 1237, Berlin, Heidelberg: Springer (1997)

16. Searle, J.R.: The construction of social reality, New York: Free Press (1995)

17. Lodder, A.: Dialaw. On Legal Justification and Dialogical Models of argumentation, Dordrecht: Kluwer A. P. (2001)

18. Gordon, T.: The Pleadings Game. An artificial Intelligence Model of Procedural Justice, Dordrecht: Kluwer A. P. (1995)

19. Zeleznikow, J., Bellucci, E.: Family_Mediator - Adding Notions of Fairness to Those of Interests. T. v. Engers(Ed.): Legal Knowledge and Information Systems - JURIX 2006: The Nineteenth Annual Conference on Legal Knowledge and Information Systems, Paris, France, 7-9 December 2006. Frontiers in Artificial Intelligence and Applications, 152 , Amsterdam: IOS Press, pp. 121-130 (2006) 
20. Lodder, A., Zeleznikow, J.: Developing an Online Dispute Resolution Environment: Dialogue Tools and Negotiation Support Systems in a Three-Step Model, 10 Harvard Negotiation Law Review, pp. 287336 (2005)

21. Bellucci, E., Zeleznikow, J.: Developing Negotiation Decision Support Systems that Support Mediators: A Case Study of the Family_Winner System, AI \& Law, 13 n. 2, pp. 233-271 (2005)

22. Walton, D.: The Place of Dialogue in Logic Computer Science, and Communication Studies, Synthese 123, pp. 327-346 (2000)

23. Walton, D.: The New Dialectic. Conversational Context of Argument, Toronto: The University of Toronto Press (1995)

24. Sartor, G.: A Teleological Approach to Legal Dialogue, EUI working paper LAW No. 28 (2006)

25. Sloane, T. O.: Reinventing inventio”, College English, vol. 51, num. 5, pp. 461-473 (1989)

26. Hohmann, H.: The Dynamics of Stasis: Classical Rheorical Theory and Modern Legal Argumentation, 34 American Journal of Jurisprudence, pp. 171-197 (1989)

27. Leff, M.: Rhetoric and Dialectic in the Twenty-First Century, Argumentation 14, pp. 241-254 (2000)

28. Fumaroli, M. : L’Âge de l'éloquence : rhétorique et « res literaria » de la Renaissance au seuil de l’époque classique, Paris: Droz (1980)

29. Heath, T.: Logical Grammar, Grammatical Logic, and Humanism in Three German Universities, Studies in the Renaissance, num. 18, pp. 9-64 (1971)

30. Jardine, L.: The Place of Dialectic Teaching in Sixteenth-Century Cambridge, Studies in the Renaissance, 21, pp. 31-62 (1974)

31. Hamilton, D.: Instruction in the making: Peter Ramus and the beginning of modern schooling, Annual Convention of the American Educational Research Association, Chicago, 21-25 April (2003)

32. Grau-Arau, A. : Humanisme i Escolàstica en el Renaixement, Comprendre num. 2, 1 , pp. 5-14 (2000)

33. Olmos Gómez, P.: La polémica antiescolástica y la Lógica humanista en la España del siglo XVI. Revista de Hispanismo Filosófico 12, pp. 65-83 (2007)

34. Pozzo, R.: Logic and Metaphysics in German Philosophy from Melanchton to Hegel, in W. Seet (et al.), Approaches to Metaphysics, Berlin, Heidelberg: Springer Verlag, pp. 61-74 (

35. Meerhoff, K.: Logic and Eloquence: A Ramusian Revolution?, Argumentation, num. 5, pp. 357-374 (1991)

36. Giuliani, A. Les règles de la 'discussion légitime’ dans la logique de Port-Royal”, Argumentation 5, pp. 263-273 (1991)

37. Kelley, D.R. (1988) Jurisconsultus Perfectus: The Lawyer as Renaissance Man”, Journal of the Warburg and Courtauld Institutes num. 51, pp. 84-102 (1988)

38. Pozzo, R.: Ramus and Other Renaissance Philosophers on Subjectivity”, Topoi num. 22, pp. 5-13 (2003)

39. Ong, W.J.: Ramus, Method, and the Decay of Dialogue. From the Art of Discourse to the Art of Method (1959), Chicago and London: The University of Chicago Press (1983)

40. Perelman, C.: Pierre de la Ramée et le déclin de la rhétorique, Argumentation num. 5, pp. 347-356 (1991)

41. Casanovas, P., Poblet, M. La médiation ou la puissance imaginative du dialogue, Colloques de Cérisy, La Sérendipité dans les sciences, les arts et la décisión, Juillet 28 (2009)

42. Walton, D.: An Automated System for Argument Invention in Law Using Argumentation and Heuristic Search Procedures, Ratio Juris, vol. 18, n. 4, pp. 434-463 (2005)

43. Macagno, F.; Walton, D. Argumentative Reasoning Patterns, Artificial Intelligence and Law, 11, pp. 1-43 (2003)

44. Eemeren, van F.H.; Houtlosser, P.: Rhetorical Analysis within a Pragma-Dialectical Framework”, Argumentation, 14, pp. 293-305 (2000)

45. Jackson, S.: 1998. Disputation by Design. Argumentation 12, pp.183-198 (1998)

46. Jacobs, S.: Maintaining neutrality in dispute mediation: managing disagreement while managing not to disagree, Journal of Pragmatics 34, pp. 1403-1426 (2002)

47. Aakhus, M.: Designing reflective dialogue to support learning from experience”, SIGGROUP Bulletin 22 (2): 29-37 (2001) 
48. Aakhus, M.: Technocratic and Design Stances Toward Communication Expertise: How GDSS Facilitators Understand Their Work, Journal of Applied Communication Research, 29 (4): 341-371 (2001)

49. Aakhus, M.: Neither Naïve nor Critical Reconstruction: Dispute Mediators, Impasse, and the Design of Argumentation. Argumentation 17: 265-290 (2003)

50. Aakhus, M., Aldrich, A.: Crafting Communication Activity: Understanding Felicity in 'I wish I...' Compliments”. Research on Language and Social Interaction 35, 4, pp. 395-425 (2002)

51. Atkinson, C. : Inventing Inventors in Renaissance Europe Polydore Vergil's De inventoribus rerum. Spatmittelalter und Reformation Neue Reihe No. 33. Mohr Siebeck (2007)

52. McNally, J.R.: Rudolph Agricola’s De Inventione Dialectica Libri Tres: A Translation of Selected Chapters, Communication Monographs 34, 4, pp. 393-422 (1967)

53. MacNally, J. R.: Dux Illa Directrixque Artium: Rudolph’s Agricola’s Dialectical System, Quartely Journal of Speech vol. 52, num. 4, pp. 337-347 (1966)

54. McNally, J. R.: 'Prima pars dialectica': The Influence of Agricolan Dialectic Upon English Accounts of Invention, Renaissance Quarterly, 21, 2, pp. 166-177 (1968)

55. McEvoy, S.: Issues in Common Law Pleading and Ancient Rhetoric, Argumentation, 5, 3, pp. 245261 (1991)

56. Mack, P.: Agricola's Use of the Comparison between Writing and the Visual Arts, Journal of the Warburg and Courtauld Institutes, num. 55, pp. 169-179 (1992)

57. Feteris, E.T.: A Survey of 25 Years of Research on Legal Argumentation, Argumentation 11, pp. 355-376, (1997)

58. Thagard, P., Shelley, C.: Abductive reasoning: Logic, visual thinking, and coherence, in M.L. Dalla Chiara et al. (eds.) Logic and Scientific Methods, Dordrecht Kluwer, p.p. 413-227 (1997)

59. McEvoy, S.: The Construction of Issues: Pleading Theory and Practice, Relevance in Pragmatics, and the Confrontation Stage in the Pragma-Dialectical Theory of Argumentation, Argumentation 13, pp. 43-52 (1999)

60. McEvoy, S. : L’invention defensive. Poétique, linguistique, droit. Paris: Éditions Métailié (1995)

61. Simon, H.A.: The Sciences of the Artificial, Cambridge: MIT Press (1996)

62. Lederach, J.P.: Moral Imagination. The Art and Soul to Building Pace. Cambridge: MIT Press (1966)

63. Casanovas, P.; Poblet, M.: Microfoundations of Restorative Justice: A General Framework, in R. Mackay, M. Bošnjak, J. Declerck, C. Pelikan, B.v. Stokkom, and M. Wright (eds.) Images of Restorative Justice Theory, Verlag für Polizeiwissenschaft, Frankfurt am Main, pp. 234-258 (2007)

64. Umbreit, M., Bradshaw, W., Coates, R. B.: Victim Sensitive Offender Dialogue in Crimes of Severe Violence. Differing Needs, Approaches, and Implications, Office for Victims of Crime, U.S., Department of Justice, (2001)

65. Polanyi, K.; Arensberg, C.M., Pearson, H.W. et al.: Trade and Markets in the Early Empires (1957), Glencoe: Free Press (1957)

66. Aquino, K., Tripp, T., Bies, R.J.: Getting Even or Moving On? Power, Procedural Justice, and Types of Offense as Predictors of Revenge, Forgiveness, Reconciliation, and Avoidance in Organizations, Journal of Applied Psychology 91, 3, pp. 653-668 (2006)

67. Goyet, F. : Le Sublime 'lieu commun' : L’Invention Rhétorique dans l’Antiquité et à la Renaissance, Paris : Honoré Champion, (1996)

68. Goyet, F. : La prudence : entre sublime et raison d'état, in I. Cogitore et F. Goyet (dir.) Devenir roi. Essais sur la littérature adressée au Prince, Grenoble, ELLUG, p.p. 163-180 (2001)

69. Chase, V.M., Hertwig, R., Gigerenzer G.: Visions of Rationality, Trends in Cognitive Sciences, 2, 6, pp. 206-214, June (1998) 